\title{
Racialized places, racialized bodies: the impact of racialization on individual and place identities
}

\author{
Joshua F. Inwood · Robert A. Yarbrough
}

Published online: 22 September 2009

(C) Springer Science+Business Media B.V. 2009

Scholarship in Geography and other disciplines understands race as a social construction (Inwood and Martin 2008; Melamed 2006; Hoelscher 2003; Nash 2003; Delaney 2002; Holloway 2000; Omi and Winant 1994). This line of reasoning argues that ideas about race are historically created and contemporarily recreated, enforced and manifest through everyday actions (Marable 2002). As geographers have increasingly focused on the ways in which the social construction of race is related to the construction of particular places and spatial relations, a consensus has emerged that place and race are inextricably linked (Kobayashi and Peake 2000). These connections between place and race have led Holloway (2000, p. 197) to observe that we need to uncover and unpack the relationship between race and place and conceptualize it within its historical and geographical frameworks. An integral aspect of placing the concept

As co-editors of this issue, we worked collaboratively on this introductory piece. As such, we share responsibility for any errors or omissions.

J. F. Inwood

Department of Geology and Geography, Auburn University, Suite, Haley Center, Auburn, AL 0316N, USA e-mail: jfi0001@auburn.edu

\section{R. A. Yarbrough ( $ه)$}

Department of Geology and Geography, Georgia Southern University, P.O. Box 8149, Statesboro, GA 30460, USA

e-mail: ryarbrough@georgiasouthern.edu of race within a spatial context is the examination of the relationship between the construction of racialized identities and the racialization of place. With this broad recognition in mind, the idea for this special issue of GeoJournal emerged from a series of organized sessions at the 2007 Association of American Geographers meeting held in San Francisco, California. The sessions were organized around an exploration of the ways race is dialectically linked with constructions of place and space.

Processes of racialization involve the use of biological criteria (i.e. phenotype etc.) to separate people into distinct groups for the purpose of domination and exploitation. For example, since modern U.S. society was historically founded on concepts of racial exclusion, race remains integral to the contemporary workings of state policy and affects the lives of all members of society. Goldberg (2002, p. 49) suggests, "[modern U.S. society] has been about increasingly sophisticated forms of racial formation, power and exclusion", which in turn require more sophisticated forms of analysis. Thus social scientists have sought to discern how and to what degree such processes of racialization have resulted in the construction of individual and group identities within specific historical and geographic contexts (e.g. Pulido 2006; Bonilla-Silva 2004). Racialization of place is a process of constructing particular geographic landscapes that help define and reinforce racialized social hierarchies, thus facilitating domination and exploitation. 
As efforts to interrogate race and place continue, it becomes clear that to "critically engage with race and racism requires an inter-and-multidisciplinary effort" (Nash 2003, p. 638) focused on the multi-layered and contested nature of racialized identifies. Much of the current work on race in the social sciences is informed by and through an anti-essentialist agenda that seeks to:

Deconstruct race as a naturalized hierarchy of biologically distinctive human groups while exploring processes of racialization which place individuals and groups within racial categories and have material effects in terms of the unequal distribution of power and wealth (Nash 2003, p. 639).

The ways in which processes of racialization have shaped the identities and lives of individuals as well as racial/ethnic geographies and landscapes have served as foci for many contemporary geographers. Specifically, geographers have explored the creation of landscapes of social exclusion (e.g. Hoelscher 2003; Delaney 1998; Schein 1997), the interlinkages between the prison industrial complex and the economically oppressed (e.g. Gilmore 2007), and the connections between Black experiences in the Diaspora and the politics of place (McKittrick and Woods 2007). In addition, geographers have begun to apply a racialization perspective to analyses of both nativeborn and immigrant groups in specific geographic and temporal contexts and at multiple scales (Pulido 2006; Winders 2005). As geographers have continued to interrogate the relationship between racialization and place, researchers have stressed the need to look at how race lies at the intersection of a multiplicity of differences that are produced in conjunction with one another. The recognition that racialization depends in part on the intersection of identity positions or subjectivities (e.g. race, gender, class, sexuality, etc.) has both problematized the concept of race and fueled a richer, more sustained engagement with identity construction (Valentine 2007). Given this history, race is manifest in all aspects of cultural life, including, as we contend in this special issue, in the construction of place and the reinforcement of racialized identities. Thus a multifaceted relationship exists between place and race wherein places are racialized while places also structure, construct, and re-produce racialized individual identities.
The papers collected here, while diverse in outlook, share a focus on the link between the social construction of space and place and the production of racialized identities. All of the contributions to this special issue are empirical projects that interrogate some aspect of racialization at scales ranging from the body to the neighborhood to the region. In the first paper, Bobby Wilson provides an historical account of the ways in which race and economics intersected in the U.S. South following the end of the Civil War. Wilson explores the contradictions surrounding wage labor following the end of slavery and the imposition of Jim Crow Segregation. According to Wilson what emerges in the post-bellum U.S. South is a kind of "flexible racism" that resolved the contradictions inherent in commodity exchange and removed barriers that were part of the slave economy that had prevented African Americans from taking part in the exchange of commodities.

The second paper by Ellen Hostteter argues that emotion plays a critical role in processes of racialization. Through her examination of the landscape of public housing development in Charlotte, North Carolina and Lexington, Kentucky she examines how the human emotions of fear and disgust are linked with the creation of race. Her work points to the ways federal, state and local actors are engaged in a complex process of landscape creation which is linked to powerful feelings that help to construct racialized landscapes.

Leela Viswanathan through a case study of social planning practices in contemporary Toronto reveals how several ethnic and racial groups forged a collective identity to contest the racialization of their communities. Drawing from personal experience and empirical research this article examines the challenges involved in engaging with anti-racist social planning activities within the framework of neo-liberal economic policies. Importantly this work speaks to the multiplicity of factors involved in the racialization process and the contradictions that simultaneously push socially conscious groups together while also ripping them apart. In so doing, Viswanathan places the process of racialization within a wider North American framework.

By examining the changing ethnic makeup of central Texas Joy Adams' looks at how ethnic festivals are playing an increasingly important role in maintaining historical claims of German-American identity in central Texas. This work intersects with critical 
landscape studies and the production of race through an examination of the way German-American communities and German-themed festivals mirror processes of racialization that have been present for at least 150 years. Of critical importance is the way the migration of Hispanics and Anglos has contributed to the changing role ethnic festivals are playing in an increasingly diversified central Texas landscape.

The fifth and final paper draws from racialization theory to examine the way Central American immigrants experience the racialization process in Atlanta, GA. In so doing, Robert Yarbrough argues that even though immigrants from Central America come from a diversity of backgrounds, they often experience a form of racialization in Atlanta that lumps them into a generic 'Mexican' racialized category. Such cases of mistaken identity give Central American migrants a kind of cohesive racial experience around which the adoption of a Hispanic identity coalesces. Yarbrough then connects this argument with settlement patterns and points to potential linkages between settlement patterns and the experiences of Central American immigrants in Atlanta.

Our hope is that the papers contained herein contribute to the extant research on racialization within the discipline by offering a multifaceted set of empirical pieces that incorporate fundamental theorizations from geography. In future research on racialization in geography, we foresee the continuation of examinations of the influence of geographic concepts and theorizations including but not limited to scale, racialization of space/place, and the productive/constitutive power of place in (re)constructing racialized identities.

\section{References}

Bonilla-Silva, E. (2004). From bi-racial to tri-racial: Towards a new system of racial stratification in the USA. Ethnic and Racial Studies, 27(6), 931-950.
Delaney, D. (1998). Race, place, and the law, 1836-1948. Austin, TX: University of Texas Press.

Delaney, D. (2002). The space that race makes. Professional Geographer, 54(1), 6-14.

Gilmore, R. (2007). Golden Gulag: Prisons, surplus, crisis, and opposition in globalizing California. Berkley: University of California Press.

Goldberg, D. T. (2002). The racial state. Oxford: Blackwell.

Hoelscher, S. (2003). Making place, making race: Performances of whiteness in the Jim Crow South. Annals of the Association of American Geographers, 93(3), 657-686.

Holloway, S. (2000). Identity, contingency, and the urban geography of 'race'. Social and Cultural Geography, 1(2), 197-208.

Inwood, J., \& Martin, D. (2008). Whitewash: White privilege and racialized landscapes at the University of Georgia. Social and Cultural Geography, 9(4), 373-395.

Kobayashi, A., \& Peake, L. (2000). Racism out of place: Thoughts on whiteness and an antiracist geography in the new millennium. Annals of the Association of American Geographers, 90(2), 392-403.

Marable, M. (2002). The great wells of democracy: The meaning of race in American life. New York: Basic Books.

McKittrick, K., \& Woods, C. (Eds.). (2007). Black geographies and the politics of place. Boston: South End Press.

Melamed, J. (2006). The spirit of neoliberalism: From racial liberalism to neoliberal multiculturalism. Social Text, 24(4), 1-24.

Nash, C. (2003). Cultural geography: Anti-racist geographies. Progress in Human Geography, 27(5), 637-648.

Omi, M., \& Winant, H. (1994). Racial formation in the United States: From the 1960s to the 1990s. New York: Routledge and Kegan Paul.

Pulido, L. (2006). Black, brown, yellow and left: Radical activism in Los Angeles. Berkley: University of California Press.

Schein, R. (1997). The place of landscape: A conceptual framework for interpreting an American scene. Annals of the Association of American Geographers, 87(4), 660-680.

Valentine, G. (2007). Theorizing and researching intersectionality: A challenge for feminist geography. The Professional Geographer, 59(1), 10-21.

Winders, J. (2005). Changing politics of race and region: Latino migration to the US south. Progress in Human Geography, 29(6), 683-699. 